\title{
Inventing the EU as a Democratic Polity: Concepts, Actors, Controversies. By Claudia Wiesner. Palgrave Studies in European Political Sociology, Palgrave MacMillan, 2019. 309 pp. ISBN: 978-3-030-06848-6
}

\author{
Teija Tiilikainen ${ }^{1,2}$ \\ 1 The European Centre of Excellence for Countering Hybrid Threats, FI \\ 2 European University Institute, IT \\ Teija.Tiilikainen@fiia.fi
}

Keywords: EU's governance; EU's democratic system; EU's political concepts; EU's citizenship

The history of European integration is most often written from a firmly institutional perspective. That's why Claudia Wiesner's idea of focusing on conceptual controversies in her approach to the construction of the EU's democratic polity can be warmly welcomed. A glance at the book's table of contents reveals that the focus is on key concepts behind a democratic polity such as parliamentarism, government and citizenship. They are approached from different theoretical perspectives in the three main thematic parts of the book.

Wiesner's broader theoretical approach presented in the introductory chapters is very promising as she defines the notion of conceptual controversies in a very broad sense both what comes to the actors and political processes involved. Wiesner thus does not only intend to study how the key concepts related to the EU's democratic polity came into being and shaped the current Union but also how the Union's own conceptual realities and practices have further shaped these concepts. The actors argued to be involved in shaping the concepts are not limited to the key political and governmental actors but also the role played by academic actors and discourses are envisaged to be studied.

The conceptual and methodological framework Claudia Wiesner develops for her study is well elaborated and ambitious. The introductory chapters lay out the basic vocabulary and philosophy of a conceptual history approach with Quentin Skinner and Reinhart Koselleck as the key intellectual sources. Along with this approach concepts are first of all defined as discursive structures which are essential in constructing social realities. Moreover, concepts are not seen to have any significance independent of the particular contexts in which they appear. Their meaning shall rather be seen through an ever-changing process of controversies and debate. When studying conceptual controversies in the construction of the EU's democratic polity this contingency of concepts means that their meanings shall be studied against their key historical and social contexts. The novelty that this perspective of conceptual 
history brings to the EU studies thus implies distancing from the common approach where the Union's democratic practices are assessed against one static concept of representative democracy.

\section{The Challenges in Studying Conceptual Controversies}

Having presented the broader theoretical approach, Wiesner sets to study the construction of the EU's democratic polity in the framework of three different parts. The first of them deals with the origins of the various components of this polity and the way they became a part of the discourse on European unification. The second part takes this discussion further to the more recent developments around the EU's governance, parliamentarism and citizenship. The final part includes a slightly more specific discussion on the role of market liberalism and the alleged neoliberal trends - on the various components of the EU's democratic polity.

A careful review of the book reveals the challenges with the application of Claudia Wiesner's methodology. A full methodological consistency would have required a more strict demarcation of the topic. It is obvious that the analysis of the conceptual controversies in the construction of the EU's democratic policy now does not follow such a rigorous conceptual approach that is laid out for the book. The conceptual controversies the book focuses on are instead of a much more general character and in most cases follow the quite well-known narratives revolving around the history of European integration. Including several key constituents of a democratic polity might have been an overly ambitious goal, as it has clearly led to a compromise taking place on the methodology as well as a superficiality of the analysis. By focusing on any of the key components laid out, parliamentarism, governance or citizenship, a more rigorous application of the methodology could have been possible. This could have led to interesting and novel findings concerning the more in-depth conceptual controversies related to the meanings of the key concepts as emerging in different historical contexts. By narrowing down the focus also the initial idea of going beyond the official fora for EU policymaking and covering scholarly debates could have been better followed. Mapping conceptual controversies now means more or less that the key differences of opinion among the leading policy-makers in the EU are brought to the fore.

While affecting the logic and consistency of Claudia Wiesner's book, the mentioned shortcomings in applying the theoretical and methodological approach do not deprive the book of its academic value and interest. In the following I will pick up a couple of conceptual discussions which I find to be particularly interesting with respect to the emergence of the EU's democratic polity.

\section{Parliamentarism and Citizenship - Conceptual Approaches}

The different chapters in Claudia Wiesner's book that deal with the role of the European Parliament provide a good analysis on how the current role and powers of the European Parliament came into being. In addition to the treaty-based changes in its competences also the more informal changes in political practices are being acknowledged. It is a pity that an analysis that is so rich in details remains quite weak concerning the conceptual dimension. It is only at a quite late stage of her book that Wiesner introduces some important conceptual dimensions to parliamentarism such as those of the working parliament and debating parliament. The very basic conceptual division of parliamentarism into parliamentarism as control of the political executive and parliamentarism of a separation-of-powers type of political system is practically not discussed at all. This distinction, however, has affected the political visions on how the powers of the European Parliament should be constructed.

One of those key conceptual controversies related to the construction of the EU's democratic polity, which becomes well identified in Wiesner's book, deals with the political essence 
of the EU. The framework of the EU's democratic polity is greatly dependent of whether the Union is seen as an intergovernmental arrangement between sovereignties or as a sovereign in the making. But this more principled dividing line should not let to overshadow all those more nuanced conceptual controversies dealing with different forms of governance, parliamentarism or citizenship in European politics throughout the history of European integration. It is quite obvious that irrespective of the constantly on-going debate about the Union's essence, more detailed discussions on the specifics of the EU's democratic policy have still been going on quite separately from this macro-level discussion.

In this respect the discussion of the EU citizenship - divided between the three different chapters - forms the richest thematic dimension of the book. The topic is not addressed from the ambitious conceptual perspective of the introductory chapter, so it suffers from the same ambiguity of approach as the other thematic dimensions. The different conceptual building blocks of an EU citizenship are, however, analysed in a more comprehensive manner than the other components of democratic polity and with the conceptual landscape being broadened well beyond the question of the EU's key essence.

The character of citizenship in a community such as the EU is a complex issue and in Wiesner's hands the analysis of it becomes fluent and well-structured. The analysis about the connection between a European demos and the material content of EU citizenship is well structured and interesting. Concerning this topic, there would also be some new data to be analysed from the conceptual point of view - namely the application of the EU's Charter of Fundamental Rights, which became an equal part of the treaties in the context of the Lisbon Treaty. In the light of existing court practice, one could have further extended the conceptual analysis of EU citizenship, which would also have taken the analysis beyond the more explicit definition of the EU citizenship to be found in the treaties.

In conclusion, taking into account the increasing polarization of European societies regarding the question of European integration, Inventing the EU as a Democratic Polity touches upon one of the most important themes for the EU's future. The EU cannot survive without a proper political legitimacy, which again, is highly dependent on how the issues of political accountability and the popular sense of inclusion are addressed at the Union level. Wiesner's work forms a welcome contribution to this discussion.

\section{Competing Interests}

The author has no competing interests to declare.

How to cite this article: Tiilikainen, Teija. 2019. "IInventing the EU as a Democratic Polity: Concepts, Actors, Controversies. By Claudia Wiesner. Palgrave Studies in European Political Sociology, Palgrave MacMillan, 2019. 309 pp. ISBN: 978-3-030-06848-6." Redescriptions: Political Thought, Conceptual History and Feminist Theory 22(1): 80-82. DOl: https://doi.org/10.33134/rds.310

Submitted: 30 October 2019 Accepted: 30 October 2019 Published: 03 December 2019

Copyright: (c) 2019 The Author(s). This is an open-access article distributed under the terms of the Creative Commons Attribution 4.0 International License (CC-BY 4.0), which permits unrestricted use, distribution, and reproduction in any medium, provided the original author and source are credited. See http://creativecommons.org/licenses/by/4.0/.

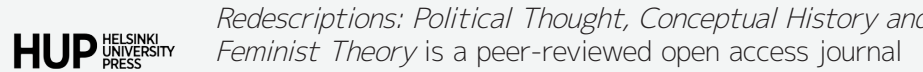
published by Helsinki University Press. 